\title{
Advisor Akira Iriye Received the Japan Foundation Award for 2013
}

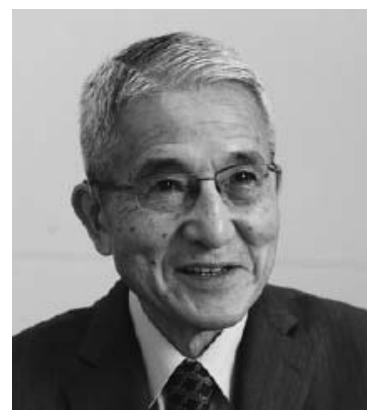

Akira Iriye 入江昭, Professor Emeritus of Harvard University, was awarded the Japan Foundation Award for 2013. Commenting on the award, Prof. Iriye said, "Exactly 60 years ago, I visited the U.S. to study for the first time. It is my great honor, and I would like to express my appreciation, to receive the Japan Foundation Award on this memorable occasion. I'll always remember those who have made great efforts for promoting academic and cultural exchanges beyond borders internationally, and I will continue trying to do my best."

Prof. Iriye has long served as an advisory committee member of the Japan Foundation Center for Global Partnership. His contributions to Japan Foundation projects include "Symposium on the Twentieth Century" (1983), "20th Century Symposium: The End of the Century, the Future in the Past" (1993), in addition to the lectures and seminars on the history of Japan-U.S. relations and international relations among the United States, Europe, and China. The Japan Foundation also supported publishing and translating his works, in particular, publishing Partnership: The United States and Japan, 1951-2001, edited by Akira Iriye and Robert Wampler (2001), and translating into Vietnamese his Nihon no gaikō: Meiji Ishin kara gendai made 日本の外 交：明治維新から現代まで (Japanese Diplomacy: From the Meiji Restoration to the Present, 1966) and his Shin Nihon no gaikō: Chikyūka jidai no Nihon no sentaku 新日本の外交: 地球化時代の日本の選択 (Japanese Diplomacy Revisited: Japan's Choice in the Age of Globalization, 1991).

Prof. Iriye has written widely on American diplomatic history and Japanese- American relations. Among his works are Pacific Estrangement: Japanese and American Expansion, 1897-1911 (1972); Power and Culture: The Japanese-American War, 1941-1945 (1981); Nichi-Bei kankei gojūnen: Kawaru Amerika, kawaranu Amerika 日米関係五十年: 変わるアメリカ, 変わ らぬアメリカ (Fifty Years of Japanese-American Relations: Changes and Constants in America, 1991); China and Japan in the Global Setting (1992); The Globalizing of America (1993); and Cultural Internationalism and World Order (1997).

Born in 1934, Akira Iriye graduated from Seikei Senior High School and moved to the United States in 1953 on a scholarship from the Grew Bancroft Foundation. He graduated from Haverford College in 1957 and received a 
Ph.D. in History from Harvard University Graduate School in 1961. After holding positions in a number of institutions, he became Charles Warren Professor of American History at Harvard in 1991 and Professor Emeritus in 2005. He specialized in American diplomatic history, especially as relates to Japan. As a U.S.-based Japanese historian, Prof. Iriye has made significant contributions to his field over a long period of time. In his approach he emphasizes ideological and cultural impact, and in international history he advocates that research incorporate a multinational perspective that goes beyond the diplomatic history of one country and two-way interactions. He is recognized as "one of the people who changed the way we view the diplomatic history of America." Prof. Iriye became the first Japanese citizen to serve as President of the Society for Historians of American Foreign Relations and as President of the American Historical Association. He made significant contributions as a pioneer in Japan-U.S. interaction.

Copyright (C) 2014 The Japan Foundation, All Rights Reserved. http://www.jpf.go.jp/e/about/award/13/

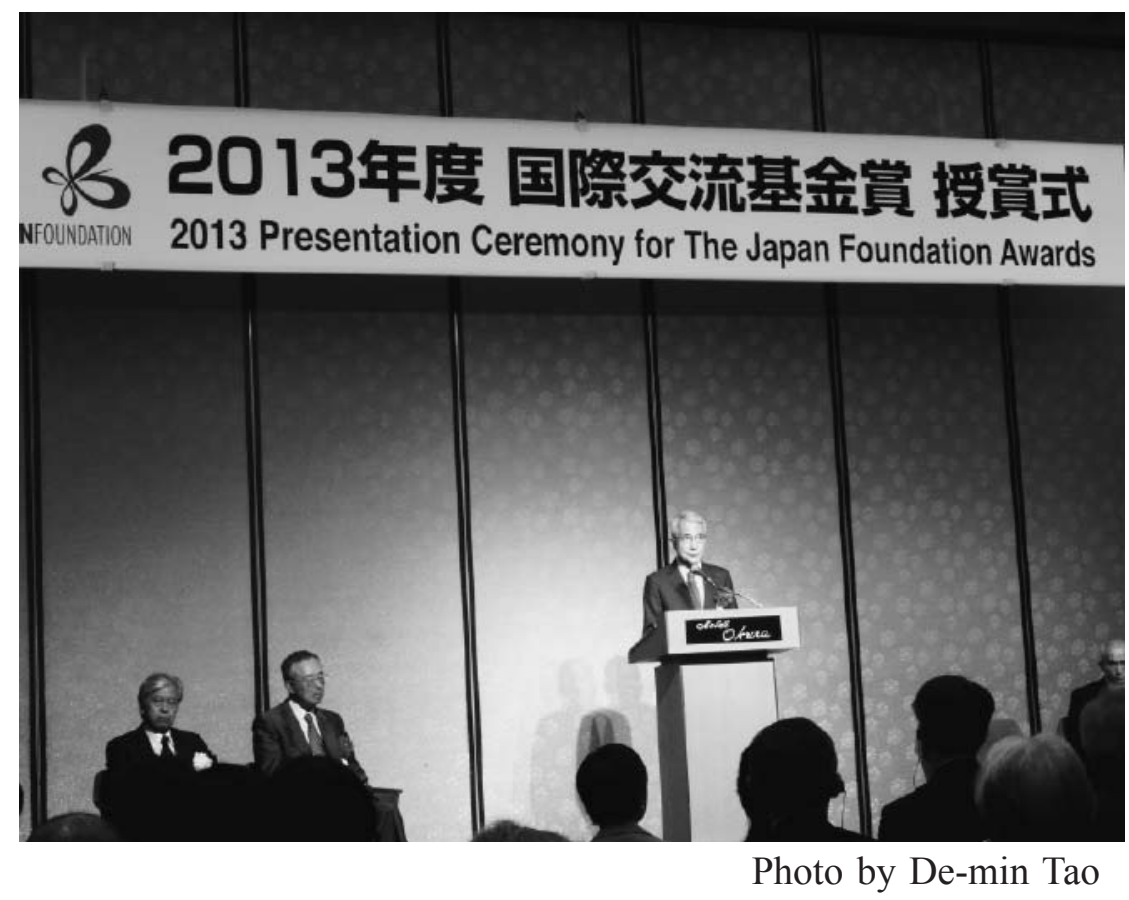

